\title{
Sustainable work for health and job longevity ${ }^{1}$
}

\author{
Maria Albin \\ Theo Bodin \\ Eskil Wadensjö
}

\section{Abstract}

While improved public health in groups with high or middle socioeconomic status (e.g., educational level) permits many to work for more years, the gap is widening for less advantaged groups, such as those with only compulsory level education. Within manual jobs, individual health status and the challenges of physical demands exceed the physical capacity of many middle-aged, and with a low bargaining power, constitute major threats to job longevity. Artificial intelligence and digitisation are also rapidly transforming the labour market, especially for lowmid grade (level) white-collar workers. Young workers often have insecure job contracts, while older workers may have a permanent position, but have a fear of leaving a safe position for a new one, and ultimately may be forced to leave their job when they are unable to meet the demands. Current economic incentives to prolong working life, often combined with more restrictive unemployment and disability benefits, may overall increase work participation but may also decrease sustainability in the more disadvantaged part of the labour market. Recent research suggests that unemployment is the most important factor behind lost working years among workers with less education, and that primary prevention, focused on the work environment rather than individual health promotion (lifestyle habits), will enhance sustainability together with inclusive welfare systems. Resilience, or reduced vulnerability, in the workforce on a macro- and workplace level can be achieved by well-established societal measures. This paper highlights the tension between two trends: increased expectations on career longevity, and increasing socioeconomic inequalities in health. This is further explored as a gap between job demands and individual capacity, and the risk of being "locked-in" or forced out when facing this scenario. Finally, macro- and micro-level measures to decrease the vulnerability for mainly manual and lowskilled workers are discussed, and more specifically in relation to the sustainable development goal: Decent work and economic growth (SDG 8).

Keywords: socioeconomic inequalities in health; job demands, labour market, resilience, decent work

\footnotetext{
${ }^{1}$ This paper is partly based on an extended abstract from a research seminar published in Socialförsäkringsrapport (Social Insurance Report) 2020:5 Förlängt arbetsliv - förutsättningar, utmaningar och konsekvenser Rapport från forskarseminariet i Umeå 15-16 januari 2020 (in Swedish).
} 


\section{Better health: but increasing inequalities}

Better health and longer lives have increased expectations on career longevity. However, these expectations need to consider the development in different parts of the workforce. While life expectancy overall has increased in Europe since 2000, the health divide between socioeconomic groups has remained constant (Southern Europe) or increased (Western, Eastern and Northern Europe (Health Inequalities in the EU, 2013). In Sweden, the overall health status in the population has dramatically improved over the most recent decades, as reflected in, for example, life expectancy (SOU, 2017). However, the socioeconomic disparities in health have increased ${ }^{2}$. Using different measures of socioeconomic status (e.g., position in the income distribution, educational level) this pattern is consistent for women, and for younger men (Hartman \& Sjögren, 2017). The associations between socioeconomic status and health are thought to be mediated through the individual resources in economy, social networks, and knowledge, as well as decision latitude throughout life (Health Inequalities in the EU 2013; SOU 2016): Good/sufficient resources and discretion at critical points in life enhance the likelihood of upward instead of downward trajectories in health and living conditions.

The most remarkable and challenging observation is that life expectancy at age 30 has seen significantly little improvement, or possibly even decreased slightly during the last three years amongst women with only compulsory ${ }^{3}$ education (Figure 1). Life expectancy at age 30, was in 2018 by educational level, 57.2 years for women with post-secondary, 54.4 years with upper secondary, and for those with only compulsory education, 51.0 years. It is noteworthy that the variation in life expectancy within each educational level over time differs between levels, decreasing for the highest level, being constant in the intermediate, and increasing in the lowest one. This indicates that health status is not only stagnating but becoming increasingly heterogeneous in groups with low socioeconomic status, while more homogenously improving in the high ones.

\footnotetext{
2 Regional differences within Sweden are small, after taking socioeconomic factors into account and tend to decrease. Based on available data the pattern is similar for those born in Sweden and abroad, with essentially the same life-expectancy at age 30 for different educational categories (SOU 2017), but the information is less complete for those born abroad (mortality as well as educational level may be somewhat underestimated).

${ }^{3}$ Compulsory education in Sweden is 9 years from age 7 but was previously shorter (6-8 years). A preschool year from age 6 was recently added, but is not relevant for the birth cohorts discussed in this paper.
} 


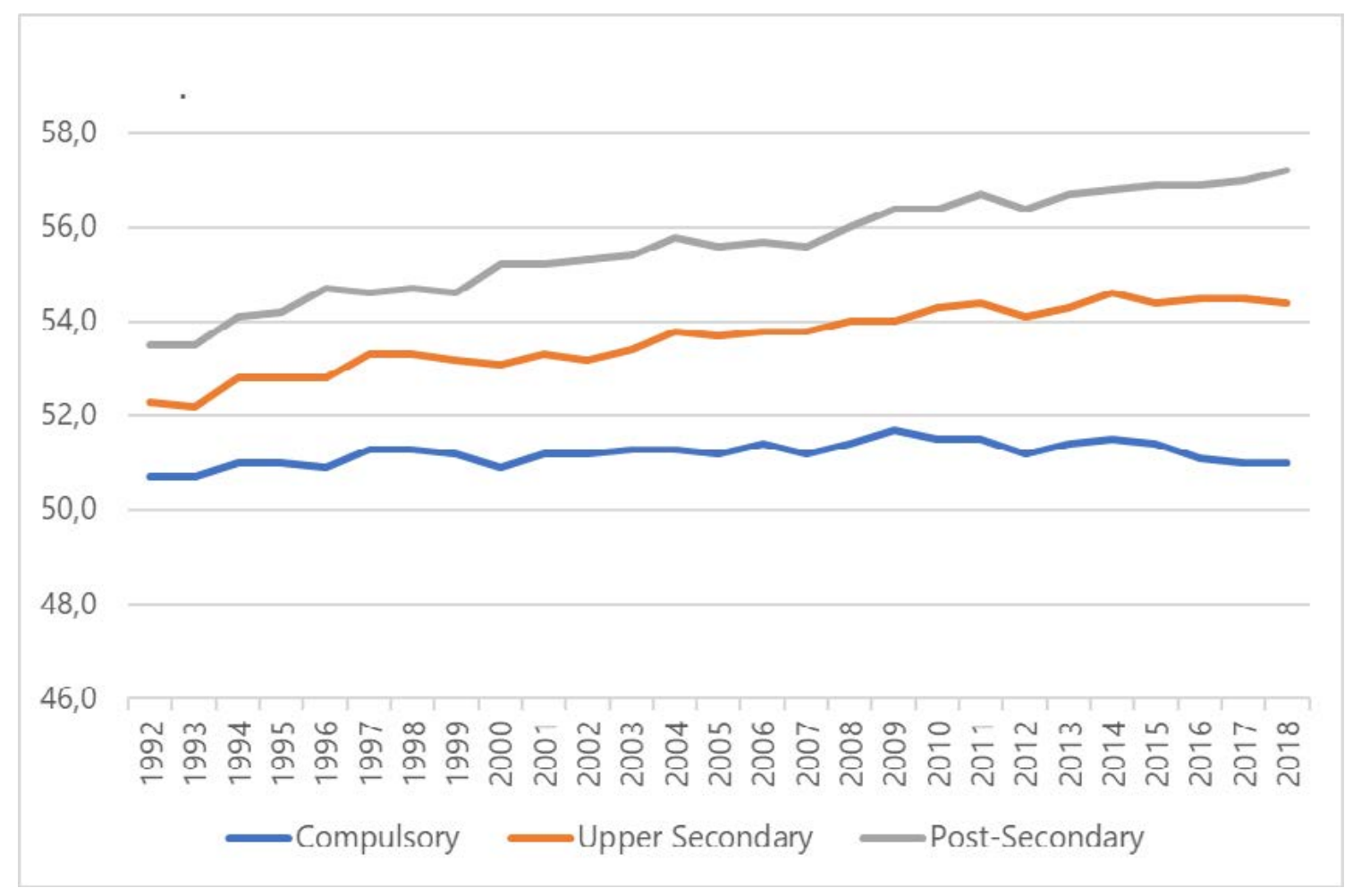

Figure 1. Remaining life expectancy at age 30 by highest attained educational level. From: Folkhälsodata (Folkhälsomyndigheten, 2020)

In the context of a sustainable working life, healthy life expectancy or years without activity limitations ${ }^{4}$ may be more relevant than longevity. Here we find what seems to be an even more accentuated socioeconomic gradient (Figure 2) than that for life expectancy: at age 30, women with compulsory education have on average only 39 remaining years without activity limitations due to poor health, i.e., the average age when you report such limitations is 69 years; for women with a long (3 years or more) post-secondary education the corresponding age is 80 years $(S C B, 2018)$. As seen for life expectancy, this is a gradient, with more expected years without activity limitations for every step of attained educational level. The pattern for men is similar, but the difference between those with the lowest and highest educational level is 10 years, i.e., one year shorter than for women.

\footnotetext{
${ }^{4}$ Activity limitation is here defined as not being able to perform activities or tasks most other people can do, for health reasons, since at least six months. Based on Global Activity Limitation Indicator (GALI), according to SCB (2018), for details and confidence intervals c.f. ibid, diagram 6.27, and Table 10.
} 


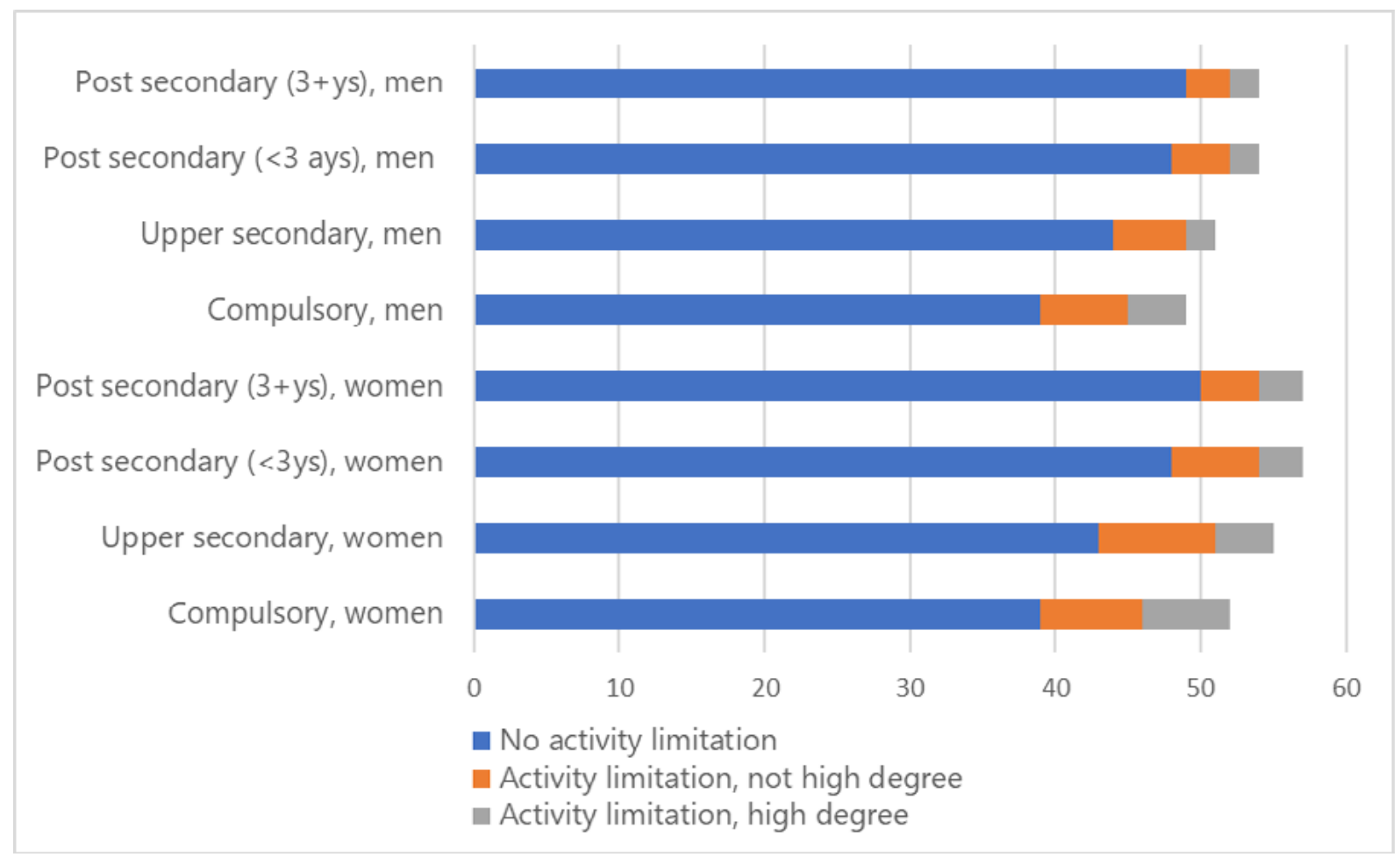

Figure 2. Remaining years with and without activity limitations at age 30, 2016-2017. From Statistics Sweden (2018)

\section{Gaps between job demands and individual capacity}

High mental and/ or physical demands characterise many jobs. Excessive demands, either mental or physical, tend to shorten working life. However, the impact will differ over the life span. Generally, excessive mental demands are especially critical at younger ages, but can be better handled by experienced workers who have a better overview and ability to sort out minor from major issues. Slower mental processing can often be compensated for by experience. A wise employer will use this shift in abilities as an advantage. Management research, linking company and employee characteristics in Germany, suggests that agediversity in a company with age-mixed teams may be associated with higher productivity (Göbel \& Zwick, 2010), although possibly mainly for non-routine tasks (complex decisionmaking, innovation; Backes-Gellner \& Veen, 2009).

However, age discrimination in opportunities for skills upgrade and professional development at the workplace may in the long term impair older workers' performance. These practices are often based on stereotypic perceptions of older workers' learning abilities, and underestimation of the rentability of such investments (Eurofound, 2020), but may change with expectations of a higher retirement age (i.e. gradual increase in age limits for employment protection, pension schemes etc).

Normal physiological ageing up to age 75 is, in general, not a limitation in relation to mental job demands (Johansson, 2016; Vingård, 2018). 
Physical work demands have a different trajectory. Excessive demands are harmful at all ages, but what is excessive changes as we age. Physical strength decreases from age 40 and on (Kenny et al., 2008), mainly in our legs and torso. Co-ordination of movements, including balance, will also decline, implying a higher risk to fall when losing balance (Torgén, 2016).

Many manual jobs have high physical demands, often combined with a low decision latitude. Although jobs with high physical demands are strongly associated with a low educational level, large groups with an intermediate educational level will have physically strenuous work in the health care sector (e.g. nurses). Individual variation in physical strength and vigour is substantial and tends to increase with age, but this is especially relevant for work that requires uncomfortable or static postures or highly repetitive movements which is usually difficult at an older age (Vingård, 2018). As compared to mental demands, experience will to a lesser degree compensate for the physiological aging. Heavy physical work does, in contrast to what is often assumed, generally not enhance physical fitness. In fact, recent research suggests an accelerated cardiovascular ageing ${ }^{5}$, also when considering relevant confounders. (Coenen et al., 2018; Holterman et al., 2018)

The prevalence of heavy work is overall decreasing, but the decline is rather slow, e.g. as indicated by Swedish data on reported lifting of heavy objects several times a day (Arbetsmiljöverket, 2016). Such work was especially common among skilled workers (30\% of the men, $20 \%$ of the women), as compared to $2 \%$ and $1 \%$, respectively, among higher whitecollar workers. Also, other physically strenuous tasks (uncomfortable or static postures, repetitive movements) were much more common among blue-collar workers.

Physical demands will often exceed individual capacity at older ages, if heavy tasks are not gradually replaced over working life. Studies of physical demands in different age groups are not consistent. However, studies based on actual measurements of the physical load do not suggest such a shift in some jobs of special concern, such as in cleaning and manufacturing (Oakman et al., 2019), construction and care (Merkus et al., 2019), or find that the shift is insufficient in relation to the physical capacity of the older workers in these trades (Merkus et al., 2019).

It is well established that both excessive emotional and physical work demands will increase the risk for early exit from the labour market. An important observation is that a high physical workload interacts with age, so that it is especially harmful for older workers (Burr et al., 2017). Danish manual workers age 50 or more, when asked about opportunities to prolong working life especially highlighted reduced physical workload (Andersen et al., 2020). While poor psychosocial working conditions contribute most to gender differences in sickness absence and disability pension, social inequalities in health-related exit from the labour market seems to be more strongly associated to physical workload (Albin et al., 2017b).

\footnotetext{
${ }^{5}$ This is hypothesized to occur from an increase in blood pressure and heart rate during work that increases the load on the vascular endothelium and on the heart but is not sufficient to give a training effect.
} 
Another critical aspect of physically demanding work is the fact that an increasing proportion of the active workforce have a chronic disease, partly due to the ageing of the workforce, but also to medical progress. Improved treatment of e.g., cardiovascular disease and cancer means that many more can return to work although they have a serious condition (Albin et al., 2017a). Those diseases will usually limit the individual capacity more in relation to physical than mental work demands. The employment gap between workers with and without chronic disease is substantially higher for workers with a low than with a high educational level, and continues to widen (Schram et al., 2019).

A well-established instrument for predicting future long-term sick-leave, disability pension and exit from the labour market, is the work-ability index, which reflects a perception of having work demands that exceed the individual capacity. A mismatch between demands and capacity may represent work demands that are excessive to most individuals, or an individual limitation. It is rather common, especially in groups with a short education, to report work demands exceeding the physical capacity (Figure 3).

\footnotetext{
25
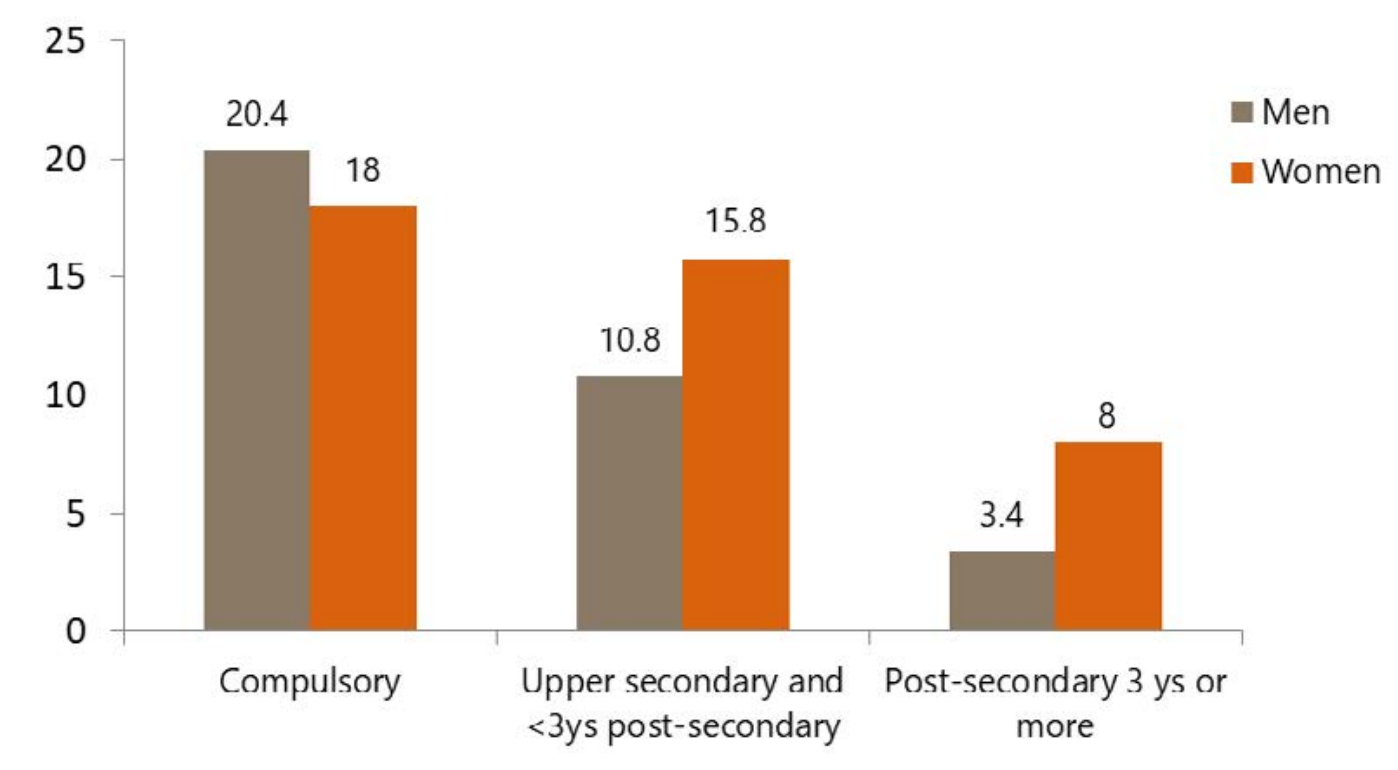

Figure 3. Proportion (\%) of occupationally active men and women by educational level, who report that physical work demands exceed their capacity, Stockholm county. From Centrum för arbets- och miljömedicin (2016).

As expected from the scenarios described above, the proportion reporting that physical work demands exceed their capacity in the population tend to increase with age (Table). On the contrary, the proportion reporting that mental demands exceed their capacity tends to decrease with age, which may at least partly be because experience can make it easier to handle mental demands. A clear concern is that one out of five women 18-34 and 50-64
} 
years of age believe that they will not be able to remain in their present job in two years for health reasons (Albin et al., 2017a, see also Table). It is noteworthy that a decreased workability in mid-life, is predictive of old age disability severity (28 years on) as measured by e.g., self-care ability in daily life (von Bonsdorff et al., 2012).

Table. Proportion (\%) of occupationally active women and men reporting that mental or physical job demands exceed their capacity, and proportion believing that they will not be able to remain in present job for health reasons in two years, County of Stockholm (from Albin et al., 2017a).

\begin{tabular}{|l|l|l|l|l|}
\hline Work demands exceed capacity & Age 18-34 & Age 35-49 & $\begin{array}{l}\text { Age 50- } \\
64\end{array}$ & Total \\
\hline Women & 12 & 11 & 16 & 13 \\
\hline Physical & 19 & 16 & 15 & 16 \\
\hline Mental & 21 & 14 & 20 & 18 \\
\hline Not in present job in two years & 6 & 8 & 13 & 9 \\
\hline Men & 11 & 9 & 10 & 10 \\
\hline Physical & 12 & 10 & 16 & 12 \\
\hline Mental & & & & \\
\hline Not in present job in two years & & & & \\
\hline
\end{tabular}

\section{Locked in and forced out?}

An obvious solution to a mismatch between job demands and individual capacity is to find a more suitable job. Being in a non-preferred job, but at the same time perceiving poor employability, has been characterised as "locked-in" (Stengård et al., 2016). According to Aronsson and Göransson (1999) one out of four workers with a permanent contract, and every second worker with a temporary contract reported that they were in a non-preferred job. Being in such a job is predictive of developing poorer mental health (Canivet et al., 2017), especially among older workers.

As mentioned before, too high job demands are predictive of early exit from the labour market. On the other hand, older workers often face greater difficulties in getting a new job than younger ones (OECD, 2019). One could thus hypothesise that aging workers, with low employability (i.e., skills in low demand) face both a lock-in (not daring to quit for fear of unemployment) with potential effects on mental wellbeing, but also in the long-run 
premature exit (forced out) because they can no longer meet the work demands ${ }^{6}$. In the absence of direct empirical support for such patterns, some indirect indications may be put forward.

A detailed study of lost working years between age 30 and 66 related to educational level from the Netherlands, found that men with a low educational level on average lost 2.6 years due to disability pension, 4.3 years due to unemployment, and less than 1 year due to exit with no income or death. Men with high educational level hade somewhat high losses due to early retirement schemes, studies, or emigration. The pattern among women was similar, but loss due to unemployment was higher (5.2 years) as was exit with no income (3.6 years; Robroek et al., 2020). Importantly, much of the loss already occurred between 30 and 50 years of age, suggesting that early interventions would be most effective.

Studies including the 40 most common occupations in Sweden found that in spite of changes in the old-age pension, with stronger economic incentives to prolong working life, substantial differences remained between occupational groups for loss of work-life expectancy due to disability pension, long-term sick-leave directly preceding disability pension, or death, while differences between men and women had virtually disappeared. In general, the loss of worklife expectancy was highest for unskilled manual occupations, and lowest among white collar occupations requiring a high educational level, with a difference of up to five years between high and low risk occupations (Kadefors et al., 2017).

Several European countries, including Sweden, have restricted access to disability pension, during later years. In Sweden, this seems to have increased the use of early retirement (drawing from the total retirement benefit so that the age pension at high age will be lower) especially in blue collar occupations: 9 out of 10 occupations with the highest increase were blue collar ones, while 10 out of 10 occupations with the lowest increase were white collar occupations. (Kadefors et al., 2019).

In summary, national policies aiming at prolonging working life through economic incentives have not achieved a levelling upwards to a full working life in many blue-collar occupations. An increased retrieval of early age pension in blue collar jobs, even though it will often be associated with economic hardship later in life, suggests that more restrictive policies on disability pension left groups of manual workers no longer able to do their job with no other option, and that measures offering a match between demands and capacity throughout working life are required, especially for manual occupations. It also makes the workforce more dependent on options for e.g., retraining and other benefits offered by collective agreements, thus accentuating the differences between unionised versus ununionised workers, and the high-end versus the low-end of the labour market.

\footnotetext{
${ }^{6}$ Reduced working hours are common towards the end of working life and may both reflect and affect health and workability.
} 


\section{Building resilience}

Climate change highlighted the vulnerability of our societies and raised a debate on how to enhance resilience. It may be argued that some global trends (i.e. globalisation, digitisation and automation) also increase the vulnerability of significant parts of the labour force, and that strategies which enhance resilience (i.e., reduces vulnerability) are urgently needed, at the workplace as well as at the macro-level, and with a holistic approach?

\section{Workplace}

One aspect of building resilience throughout working life is to identify risks associated with a certain age-span or (lack of) seniority, e.g., young and unexperienced workers have higher occupational accident rates than more senior ones (Guérin et al., 2020; Meidner, 1954), workers with caring duties will be more vulnerable to work-family conflicts (e.g., like unpredictable working hours), and older workers more vulnerable to physical strain and insufficient recovery. An age-conscious approach can, as suggested by Nilsson (2020), easily be included as part of the statutory risk assessment at the workplace. However, the Joint Programming Initiative More Years Better Lives identified important knowledge gaps regarding managers' perspective on a longer working life and organisational opportunities (Hasselhorn \& Apt, 2015).

It is often said that women are more vulnerable than men to psycho-social stress at the workplace, but more detailed analyses indicate that observed differences can largely be explained by differences in exposure (e.g., more job-strain in jobs with predominantly female workers; Theorell et al., 2016). Thus, resilience should build on increasing job control rather than promoting individual coping strategies in these sectors.

Non-discrimination, fairness, respect and being listened to, are all important aspects for job longevity. Apart from gender and ethnicity, old age is, as mentioned above, a common ground for discrimination and stereotyping. In this context it is noteworthy that there seems to be a socioeconomic gradient of perceiving being listened to by the closest manager, so that workers with short education or low income most often report not being listened to. In turn, this was longitudinally associated with exhaustion and depressive symptoms, most likely mediated through less job control (Theorell et al., 2012).

The importance of employment arrangements for occupational health has increasingly been seen as an additional dimension of exposure (Bodin et al., 2020; O'Connor et al., 2020). A temporary contract may or may not be associated with other disadvantages, determining whether it has negative health impacts on the individual. ${ }^{8}$ In general, temporary workers will tend to have a weaker voice at the workplace, less familiarity with workplace routines, less

\footnotetext{
7 The European Economic and Social Committee on 'The changing world of work and the longevity/ageing population have made several specific recommendations (2020) for the development of comprehensive national strategies.

${ }^{8}$ Another aspect of shifting employment arrangement which need further investigation with regard to working conditions and work environment are agency workers, and the self-employed outside the agricultural sector,
} 
access to skills upgrade, be less unionised, have less insurance benefits, and more likely to lose employment in case of poor health (Schram et al., 2020), this accumulation of multiple disadvantages in the employment arrangement is usually referred to as precarious employment (Kreshpaj et al., 2020). Precarious employment arrangements can lead to negative health consequences, through several direct and indirect pathways. The COVID-19 pandemic has highlighted the association between precarious employment and workplace safety, e.g. outbreaks of disease related to adverse conditions including symptomatic workers feeling obliged to come to work (Dyal et al., 2020), caring workers working at multiple facilities (Department of Health and Social Care, 2020; Dyal et al., 2020), and mortality rates at nursing homes associated with unionisation (Dean et al., 2020), thus suggesting that employment arrangements should be considered in risk assessment, and as a means to enhance resilience.

Flexibility aiming at accommodating individual needs is seen as important for extending working life. Andersen et al (2019) found in a representative sample of the Danish workforce age 50 or more, that opportunities supporting a long working-life (i.e., possibilities for more vacation, reduction of working hours, flexible working hours, access to treatment, further education and physical exercise) at the workplace were fewer among manual workers, women, and workers with disabilities. It is obviously important to identify and act upon this type of mismatch between support and needs.

The occupational health service has a dual task, to assist in risk assessment and reduction of harmful exposures, and in adapting the job to the individual worker (ILO, 1985). Access to occupational health service is thus especially important in jobs with a high risk for ill health caused by harmful exposure at work, and in jobs where employees are more likely to have health conditions that affect their work. Due to the socioeconomic gradients in both exposures and health, the need is thus overall, especially high in blue-collar occupations. Favourable changes in physical workload among those with chronic disease was shown to clearly reduce the risk for exit from paid employment (Schram et al., 2020).

It is thus a paradox that access to occupational health service is inversely related to needs in Sweden, with good access (more than four out of five) among higher managers and in occupations requiring higher education and very low access (around one out of three) among women in the service sector and men in hunting, fishing and forestry (Arbetsmiljöverket, 2016). This clearly fails to protect those at highest risk and most in need, a gap which should urgently be acted upon by the social partners or by legislation, i.e., by action at the macrolevel when the workplace level is failing.

\section{Macro level}

While the workplace level is decisive in supporting a long working life, there is a strong interdependence with legislation and welfare systems. Longer additional education is often required for a necessary shift to a career outside the current employer, or to keep 
employability during technological changes within a sector. This, however, will rarely be financed by the employer, forcing the individual worker to rely on active labour market policies and inclusive welfare systems to support the shift, and the older unexperienced worker will need the same initial mentorship as a young worker to e.g., prevent accidents. There would be less need for such leaps if life-long learning polices were widely implemented providing a gradual skills upgrade - transition possibility (see also Halvorsen, this issue).

Employment protection is also likely to contribute to resilience (decrease vulnerability), especially for older workers, workers with chronic disease, and workers with low education (Schuring et al., 2020). Low employability for those workers will, in the case of unemployment, easily trigger downwards trajectories in several aspects of working conditions. Change involving multiple adverse changes dramatically increases the risk for exit from paid employment (Schram et al., 2020), and could thus motivate a strong employment protection from a sustainability perspective.

The transfer of many caring duties from the home is key to women's work participation, this applies to childcare, meals and leisure time activities for school children, and elderly care. The Covid-19 pandemic has reminded us of this dependency. The liberation of women's potential on the labour market is still limited in many countries (e.g., unaffordable care on a low or medium income), and the quality of the services is affected by economic crises (i.e., austerity measures). It is remarkable that a high proportion woman of working age (32.7\% of those age 20-64 not in the workforce in EU 28, and 5.5\% to 19.7\% in the Nordic countries) report not actively seeking work due to caring responsibilities, with an increasing trend $(25.7 \%$ in 2007; Eurostat, 2020).

Finally, increasing health inequalities are a fundamental challenge as a driver of an increasing gap in work longevity between occupational groups, and thus calls for decisive action at a societal level.

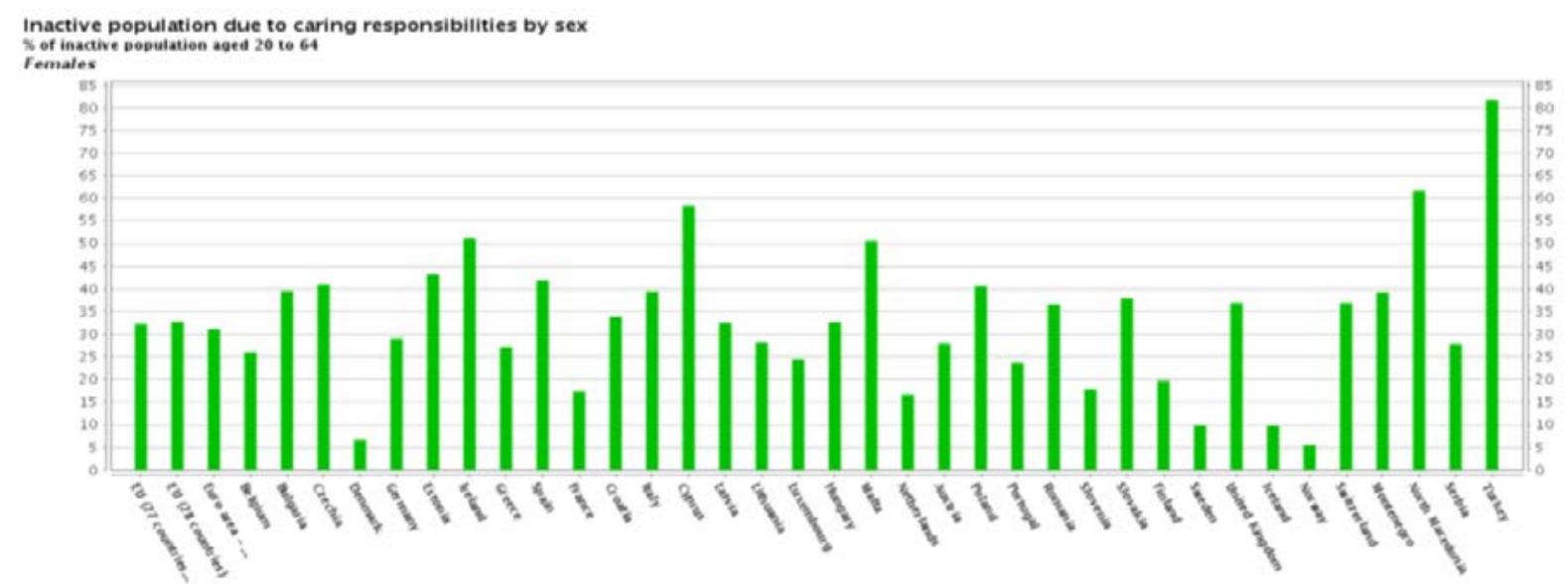

Figure 4. Proportion of inactive population aged 20 to 64 (\%) not looking for employment due to caring responsibilities (children, incapacitated adults or other family or personal responsibilities). Females. Source: Eurostat, 2020 


\section{Decent work and economic growth}

The sustainable development goal Decent work and economic growth (SDG 8) calls for providing opportunities for full and productive employment and decent work for all while eradicating forced labour, human trafficking and child labour, and promoting labour rights and safe and secure working environments. Many observations suggest a polarisation of working conditions with many improvements in the high end, and an accumulation of adverse conditions in the low end. This tends to make averages deceptive when discussing the need to develop new policies.

- While overall employment rates in e.g., EU 28 are moving upwards, the gap in employment by educational level is increasing, and seven percent of full-time workers are at risk of in-work poverty (Eurostat 2020).

- On average 15\% of all workers in the EU report exposure to smoke, gases, powder or dust at least $1 / 4$ of their working hours, among skilled blue-collar workers the corresponding proportion is 56\% and among unskilled workers 35\% (Eurofound, 2015). While substantial effort is put into decreasing the cancer burden from such exposure in the EU, permissible levels still confer unacceptably high excess mortality following a full working-life (Johanson \& Tinnerberg, 2019), especially when considering the total extra disease burden (e.g. cardiovascular disease, chronic obstructive pulmonary disease; Albin \& Gustavsson, 2020; Sjögren et al., 2020) in conflict not only with a sustainable working life but with fundamental rights to safe and healthy working conditions (European Parliament, 2000). Similarly, lack of basic safety measures for frontline workers during the covid-19 pandemic, and the extent to which this has unproportionally affected not only health care but many basic occupations, highlight the vulnerability of broad groups of workers and the need for a strong joint commitment for occupational safety and health from the social partners, government and researchers.

The commitment to Agenda 2030 from many sectors of society may offer opportunities to develop new strategies and policies for Sustainable Work and work longevity within the SDG Decent work and economic growth (see also Levi L, this issue). As an example, universities and national and regional health services are important purchasers of goods and services, with the potential to influence the development in several sectors for the better i.e., by using a socially responsible approach (European Commission, 2020). Here social partners and researchers can assist in suggesting how these demands can be phrased to have an impact, and how compliance can be followed up.

Simultaneously, national policies need to consistently consider the impact on inequalities when e.g., changing welfare systems, labour law, and labour market policies. In the absence of such consideration, inequalities will increase, and firm action is needed to reduce them (Molander, 2017). Such actions are needed to support work longevity throughout the labour market. The means to achieve this are well known, but the changing political and economic 
context calls for new ways of connecting the measures, and for researchers to actively be involved in the challenges.

\section{References}

Albin M. Liljefrost E, Parmsund M, Wadensio E. 2017(a). Äldre i arbetslivet - en omvärldsanalys [Older workers in working life - an analysis, in Swedish]. Report number 2017/00501-1. Svenska ESF-rådet.

Albin M, Gustavsson P, Kjellberg K, Theorell T. 2017(b). Arbetsmiljö och jämlik hälsa [Work environment and equity in health, in Swedish]. Underlagsrapport nr 5 till Kommissionen för jämlik hälsa S 2015:02.

Albin M., Gustavsson P. (2020). A silent epidemic: occupational exposure limits are insufficiently protecting individual worker health. Scand J Work Environ Health, 46(1), 110-112.

Andersen L.L., Jensen P.H., Meng A., Sundstrup E. (2019). Strong Labour Market Inequality of Opportunities at the Workplace for Supporting a Long and Healthy Work-Life: The Senior Working Life Study. Int J Environ Res Public Health. Sep 5;16(18):3264.

Andersen L.L., Jensen P.H., Sundstrup E. (2020). Barriers and opportunities for prolonging working life across different occupational groups: the Senior Working Life study. EurJ Public Health, 30(2), 241-246.

Arbetamilöverket (2016). Arbetsmiljön [The Work Environment, in Swedish] 2015. Arbetsmiljöstatistik Rapport 2016:2

Aronsson G., Göransson S. (1999). Permanent employment but not in a preferred occupation: psychological and medical aspects, research implications. J Occup Health Psychol, 4(2), 152-163.

Backes-Gellner U., Veen S. (2009). The impact of aging and age diversity on company performance. Retrieved from http://ssrn.com/ abstract=1346895, accessed October 10, 2020

Bodin T., Çağlayan Ç., Garde A.H., Gnesi M., Jonsson J., Kiran S., Kreshpaj B., Leinonen T., Mehlum I.S., Nen, E., Orellana C., Peckham T., Seixas N., Vanroelen C., Julià M. (2020). Precarious employment in occupational health - an OMEGA-NET working group position paper. Scand J Work Environ Health, 46(3), 321-329.

von Bonsdorff M.B., Seitsamo J., Ilmarinen J., Nygård C.H., Von Bonsdorff M.E., Rantanen T. (2012). Work ability as a determinant of old age disability severity: evidence from the 28-year Finnish Longitudinal Study on Municipal Employees. Aging Clin Exp Res, 24(4), 354-360.

Burr H., Pohrt A., Rugulies R., Holtermann A., Hasselhorn H.M. (2017). Does age modify the association between physical work demands and deterioration of self-rated general health? Scand J Work Environ Health, 43(3), 241-249.

Canivet C., Aronsson G., Bernhard-Oettel C., Leineweber C., Moghaddassi M., Stengård J., Westerlund H., Östergren P.O. (2017). The negative effects on mental health of being in a non-desired occupation in an increasingly precarious labour market. SSM Popul Health, 3, 516-524.

Centrum for Arbets och Miljömedicin 2016. Arbetshälsorapport för Stockholms län [Work health report for the County of Stockholm, in Swedish]. Stockholm 2016.

Coenen P., Huysmans M.A., Holtermann A., Krause N., Van Mechelen W., Straker L.M., van der Beek A.J. (2018). Do highly physically active workers die early? A systematic review with meta-analysis of data from 193 696 participants. BrJ Sports Med, 52(20), 1320-1326.

O'Connor A., Peckham T., Seixas N. (2020). Considering Work Arrangement as an "Exposure" in Occupational Health Research and Practice. Front Public Health, Aug 4;8:363.

Dean A., Venkataramani A., Kimmel S. (2020). Mortality Rates From COVID-19 Are Lower in Unionized Nursing Homes. Health Affairs 2020, published ahead of print September 10, https://doi.org/10.1377/hlthaff.2020.01011 Department of Health and Social Care Official Statistics. Vivaldi 1: coronavirus (COVID-19) care homes study report. Published 3 July 2020 
Dyal J.W., Grant M.P., Broadwater K., Bjork A., Waltenburg M.A., Gibbins J.D., Hale C., et al. (2020). COVID-19 Among Workers in Meat and Poultry Processing Facilities - 19 States, April 2020. MMWR Morb Mortal Wkly Rep. May 8;69(18).

Eurofound (2015). Sixth European Working Conditions Survey 2015

(https://www.eurofound.europa.eu/surveys/european-working-conditions-surveys/sixth-europeanworking-conditions-survey-2015, accessed 2020-09-25).

Eurofound (2020) Role of social partners in tackling discrimination at work, Publications Office of the European Union, Luxembourg.

European Economic and Social Committee (2020). Opinion of the European Economic and Social Committee on The changing world of work and the longevity/ageing population - The preconditions for ageing workers to stay active in the new world of work' (exploratory opinion requested by the Finnish Presidency) (2020/C 14/08). Official Journal of the European Union 15.1.2020.

Executive Agency for Small and Medium Sized Enterprises. European Commission (2020). Making socially responsible public procurement work. 71 good practice cases. Published 2020-09-10. https://op.europa.eu/en/publication-detail/-/publication/e8cf51d0-f632-11ea-991b01aa75ed71a1/language-en/format-PDF/source-search, Accessed October 6, 2020.

European Parliament (2000). Charter of Fundamental Rights of the European Union. 2000/C 364/01. http://www.europarl.europa.eu/charter/pdf/text en.pdf

Eurostat (2020). Sustainable development indicators, SDG8, https://ec.europa.eu/eurostat/web/sdi/decent-workand-economic-growth, accessed 2020-09-25.

Folkhälsomyndigheten (2020). Folkhälsodata. (ohmapp.folkhalsomyndigheten.se/Folkhalsodata/pxweb/sv/A_Folkhalsodata/A_Folkhalsodata_Bakgrundsfak ta_Demografi/MedellivsUtb.px/) Accessed 2020-02-09

Göbel C. \& Zwick T. (2010). Which personnel measures are effective in increasing productivity of older workers? (Discussion Paper No. 10-069). Retrieved from Centre for European Economic Research website: ftp://ftp.zew.de/pub/zew-docs/dp/ dp10069.pdf

Guerin R.J., Reichard A.A., Derk S., Hendricks K.J., Menger-Ogle L.M., Okun A.H. (2020). Nonfatal Occupational Injuries to Younger Workers — United States, 2012-2018. MMWR Morb Mortal Wkly Rep 69:1204-1209.

Hartman L., Sjögren A. (2017). Hur ojämlikt är Sverige? Sociala skillnader i dödsrisker: Utvecklingen över tid och skillnader mellan åldersgrupper och regioner [How unequal is Sweden? Social disparities in death risk: Development over time and differences between age groups and regions, in Swedish]. Underlagsrapport nr 4 till Kommissionen för jämlik hälsa S 2015:02.

Hasselhorn H.M., Apt W. (Editors). (2015). Understanding employment participation of older workers: Creating a knowledge base for future labour market challenges. JPI- More years better lives 2015. https://www.jpdemographic.eu/wp-content/uploads/2015/07/IPIUEP Brochure1.pdf, accessed October 10, 2020

Holtermann A., Krause N., van der Beek A.J., Straker L. (2018). The physical activity paradox: six reasons why occupational physical activity (OPA) does not confer the cardiovascular health benefits that leisure time physical activity does. Br J Sports Med, 52(3), 149-150.

International Labour Organisation (ILO) (1985). The ILO convention on Occupational Health Services No 161, ILO 1985.

Johanson G., Tinnerberg H. (2019). Binding occupational exposure limits for carcinogens in the EU - good or bad? Scand J Work Environ Health, 45(3), 213-214.

Johansson B, (2016). Cognitive ageing. In: Healthy workplaces for women and men of all ages. Knowledge compilation 2016:8, Arbetsmiljöverket 2016.

Kadefors R., Nilsson K., Rylander L., Östergren P.O., Albin M. (2017). Occupation, gender and work life exits: A Swedish population study. Ageing and Society March 20, 1-18.

Kadefors R., Nilsson K., Östergren P.O., Rylander L., Albin M. (2019). Social inequality in working life expectancy in Sweden. Zeitschrift für Gerontologie under Geriatrie 51(8): 1-10. 
Kenny G.P., Yardley J.E., Martineau L., Jay O. (2008). Physical work capacity in older adults: implications for the aging worker. Am J Ind Med, 51(8), 610-25.

Kreshpaj B., Orellana C., Burström B., Davis L., Hemmingsson T., Johansson G., Kjellberg K., Jonsson J., Wegman D.H., Bodin T. (2020). What is precarious employment? A systematic review of definitions and operationalizations from quantitative and qualitative studies. Scand J Work Environ Health, 46(3), 235-247

Meidner R. (1954) Svensk arbetsmarknad vid full sysselsättning [The Swedish Labour Market at Full Employment, in Swedish with English summary], PhD-thesis, Stockholm University. Stockholm, Konjunkturinstitutet.

Merkus S.L., Lunde L.K., Koch M., Wærsted M., Knardahl S., Veiersted K.B. (2019). Physical capacity, occupational physical demands, and relative physical strain of older employees in construction and healthcare. Int Arch Occup Environ Health, 92(3), 295-307.

Molander P. (2017). The Anatomy of Inequality: Its Social and Economic Origins- And Solutions. Melville House Publishing.

Nilsson K. (2020). A sustainable working life for all ages - The swAge-model. Applied Ergonomics 86;103082.

Oakman J., Clays E., Jørgensen M.B., Holtermann A. (2019) Are occupational physical activities tailored to the age of cleaners and manufacturing workers? Int Arch Occup Environ Health. 92(2), 185-193.

OECD. 2019. Working Better with Age, Ageing and Employment Practices, OECD Publishing, Paris.

Robroek S.J., Nieboer D., Järvholm B., Burdorf A. (2020). Educational differences in duration of working life and loss of paid employment: working life expectancy in the Netherlands. Scand J Work Environ Health, 46(1), 77-84.

Schram J.L.D, Schuring M., Oude Hengel K.M., Burdorf A. (2019). Health-related educational inequalities in paid employment across 26 European countries in 2005-2014: repeated cross-sectional study. BMJ Open, Jun 1;9(5): e024823.

Schram J.L.D., Robroek S.J.W., Ots P., Brouwer S., Burdorf A., van Zon S.K.R., Oude Hengel K.M. (2020). Influence of changing working conditions on exit from paid employment among workers with a chronic disease. Occup Environ Med, 77(9), 628-633.

Schuring M, Robroek S.J.W., Carrino L., O'Prinsen A.C., Oude Hengel K.M., Avenano M., Burdorf A. (2020). Does reduced employment protection increase the employment disadvantage of workers with low education and poorer health? J Epidemiol Community Health, 74(10), 851-857.

Sjögren B, Bigert C, Gustavsson P. (2020) The Nordic Expert Group for Criteria Documentation of Health Risks from Chemicals. 153. Occupational chemical exposures and cardiovascular disease. Arbete och Hälsa 2020;54(2).

Statens Offentliga Utredningar (2016). Det handlar om jämlik hälsa. Utgångspunkter för Kommissionens vidare arbete [About equity in health: Considerations for the work of the Commission, in Swedish]. Delbetänkande av Kommissionen för jämlik hälsa. SOU 2016:55.

Statens Offentliga Utredningar (SOU) (2017). Nästa steg på vägen mot en mer jämlik hälsa. Förslag för ett långsiktigt arbete för en god och jämlik hälsa [Next step towards more equity in health; Recommendations for longterm work for good and equitable health, in Swedish]. Slutbetänkande av Kommissionen för jämlik hälsa. SOU 2017:47.

Statistics Sweden (2018). Skilda världar? Det demografiskt delade Sverige. [Separate worlds? The demographically separated Sweden. In Swedish]. Statistiska Centralbyrån [Statistics Sweden]. Demografiska rapporter 2018:2

Stengård J., Bernhard-Oettel C., Berntson E., Leineweber C., Aronsson G. (2016). Stuck in a job: being "locked-in" or at risk of becoming locked-in at the workplace and well-being over time, Work \& Stress, 30:2, 152-172.

Theorell T., Nyberg A., Leineweber C., Magnusson Hanson L.L., Oxenstierna G., Westerlund H. (2012). Nonlistening and self-centered leadership-relationships to socioeconomic conditions and employee mental health. PLoS One, 7(9):e44119. Doi: 
Theorell T., Jood K., Järvholm L.S., Vingård E., Perk J., Östergren P.O., Hall C. (2016). A systematic review of studies in the contributions of the work environment to ischaemic heart disease development. Eur J Public Health, 26(3), 470-7.

Torgén M. (2016). Physiological ageing - physical capacity and occupational performance. In: Healthy workplaces for women and men of all ages. Knowledge compilation 2016:8, Arbetsmiljöverket.

Vingård E. (2018). Vad blir sämre och vad blir bättre när man blir äldre? [What gets better and what gets worse as you age? in Swedish] Rapport 8, Delegationen för senior arbetskraft S2018:10.

\section{About the authors}

Maria Albin is Professor of Occupational and Environmental Medicine at the Institute of Environmental Medicine, Karolinska Institutet and head of the clinical department for Occupational and Environmental Medicine serving the county of Stockholm. She chairs the SWOSH platform and was a member of the Swedish National Commission on Equity in Health. She is principal investigator for the research program A sustainable new working life - trends, health effects and governance,

Theo Bodin is Associate Professor and resident physician of Occupational and Environmental Medicine at Karolinska Institutet and the Stockholm Region. He is the principal investigator of several research programs including the PWR consortium (precariousworkresaerch.org) and he has extensive international collaboration with researchers from the EU, USA, Canada and chile.

Eskil Wadensjö is Professor of Economics at the Swedish Institute for Social Research (SOFI), Stockholm University since 1980. He was Dean of the Faculty of Social Sciences 1996-2005, has been member of several governmental commissions and contributed with studies for EU, ILO, OECD, the Nordic Council and the European Council. He was president of the Swedish Economic Association 1992-93 and of the European Association of Labour Economists 199399. 